\title{
How Moderate is Kwame Gyekye's Moderate Communitarianism?
}

\author{
J.O. Famakinwa \\ Department of Philosophy \\ Obafemi Awolowo University, Nigeria \\ famakinpekun@oauife.ed.ng, akinolanipekun@yahoo.com
}

\author{
Thought and Practice: A Journal of the Philosophical Association of Kenya (PAK) \\ New Series, Vol.2 No.2, December 2010, pp.65-77 \\ thoughtandpractice@gmail.com OR thoughtandpractice@uonbi.ac.ke \\ http://ajol.info/index.php/tp/index
}

\begin{abstract}
This article undertakes a critical examination of Kwame Gyekye's main arguments for moderate communitarianism. Contrary to the general belief among African scholars, it contends that Gyekye's moderate communitarianism, as he presents it in Tradition and Modernity (1997), is not as moderate as he believes it to be. The article also seeks to show that the gap which Gyekye claims exists between moderate or restricted and unrestricted communitarianism is not as wide as he suggests.
\end{abstract}

\section{Key Words}

Autonomy; community; communitarianism; liberalism; rights

\section{Introduction}

Professor Kwame Gyekye is a distinguished African intellectual who has made significant contributions to core issues in African and Western political philosophy. In his major book, Tradition and Modernity (1997), Gyekye presents arguments for his version of moderate communitarianism. 
This article argues that the distinction between unrestricted and restricted communitarianism, as presented in Chapter Two of Gyekye's Tradition and Modernity (1997), does not make Gyekye less of an unrestricted communitarian. This is because his moderate communitarianism implies, like the unrestricted communitarianism he rejects, the communitarian primacy thesis.

The article is divided into three main sections. The first presents the tenets of unrestricted communitarianism. In the second section, Gyekye's formulation of moderate (restricted) communitarianism is outlined. The third section attempts to give an answer to the main question of the paper - "How moderate is Professor Gyekye's Moderate Communitarianism?" The article concludes that Gyekye's arguments inadvertently support unrestricted rather than moderate (restricted) communitarianism.

\section{Unrestricted Communitarianism}

Communitarianism as a political philosophy has at least two models: the family and the moderate models. The family model communitarianism or what Gyekye describes as "unrestricted communitarianism", insists on (i) the moral supremacy of the community over the individual, (ii) the superfluity of rights in a community regulated by love and shared values, and (iii) the communal constitution of the individual (Gyekye 1997, 36-37 ; Etzioni 1998, p.x). With regard to (i), the implication is that in the case of a moral clash between the community and the individual, the community ought to be favoured. For unrestricted communitarianism, communal relationships are akin to the relationships in a typical nuclear family. All things being equal, just as a typical nuclear family is regulated by love, a human community ought to be regulated by it because love, not justice, is the first virtue of social institutions (Gyekye 1997, $66 ; 2003,36)$.

According to Gyekye, for unrestricted communitarians such as Jomo Kenyatta, John Mbiti and Ifeanyi Menkiti, the individual is wholly moulded by his/her immediate community (Gyekye 1997, 36-37). This implies that just as a parent nurtures a child, 
the individuals' worldview is defined by the community that nurtures him/her right from birth.

The primacy thesis is the bone of contention between communitarians and their rivals such as Liberals and libertarians (Sandel 1983, 1; 1992, 13; Taylor 1992, 32; Etzioni 2004, 1). The communitarian version of the primacy thesis emphasizes the moral supremacy of the community over the individual (Gyekye 2003, 35). On the other hand, the liberal or libertarian primacy thesis emphasizes the moral supremacy of the rights of the individual (Rawls 1995, 3). According to Rawls, "each person possesses an inviolability founded on justice that even the welfare of society as a whole cannot override ... the rights secured by justice are not subject to political bargaining or to the calculus of social interests"(Rawls 1995, 3-4).

\section{Gyekye's Moderate Communitarianism}

The goal of moderate communitarianism is the reconciliation of rights and social responsibilities, that is, the balancing of social forces and individual autonomy (Etzioni 1998, p.x). However, is Professor Gyekye a moderate communitarian, or simply a communitarian? The question seems to be uncalled for. Ordinarily, a small or big stone is a stone. So it would be absurd to ask whether or not a big or small stone is a stone. Similarly, it seems strange to ask if a moderate communitarian is a communitarian. Gyekye has a contrary view: for him, a moderate communitarian is not necessarily a communitarian. He distinguishes between moderate (restricted) and non-moderate (unrestricted) communitarianism. He asserts that while moderate communitarianism morally supports the need to balance individual rights and social responsibilities, unrestricted communitarianism argues for the moral supremacy of the community (Gyekye 1997, 52).

Gyekye rejects the unrestricted communitarian view on the ground that the individual is only partly, not wholly, defined by the community (Gyekye 1997, 53). According to him, moderate communitarianism aims to ascribe to both the community and the individual an equal moral standing (Gyekye 1997, 41). In Aristotle's Nicomachean Ethics, "virtue" is the disposition to always strike the mean between two incompatible 
extremes, i.e. excess (too much) and deficiency (too little) (Aristotle 1989, 352). Similarly, moderate communitarianism aims at balancing individual rights and social responsibilities. Moderate communitarians like Gyekye and Etzioni are optimistic that individual rights and social responsibilities are reconcilable (Gyekye 1997, 41; Etzioni 1998, p.x). The reconciliatory attempt is well developed by members of The Responsive Community led by Amitai Etzioni. Incidentally, Gyekye is a strong member of the editorial board of the group (Etzioni 1998, p.xx).

However, while other versions of moderate communitarianism are motivated by the need to prevent the over-celebration of rights, Gyekye's is motivated by the need to prevent the over-celebration of the community. According to Gyekye, the need to refrain from over-celebrating the community becomes necessary because various communal values and beliefs require, at times, critical evaluation and revision in order to encourage the overall development of the community (Gyekye 1997, 58). Thus the salient feature of Gyekye's moderate communitarianism is the recognition of the rights of the individual. Unlike Etzioni's moderate communitarianism, it does not really attempt the balancing of rights and responsibilities. According to Gyekye, the recognition of rights is necessary because no society is absolutely communal or absolutely individualistic (Gyekye 1997, 41). In Gyekye's view, moderate communitarianism will not oppose the doctrine of individual rights for the reason that the individual and the community, while closely interacting, must maintain their unique spheres.

According to Gyekye, rights are so important that "at both theoretical and practical level, communitarianism cannot set its face against individual rights" (Gyekye 1997, 64). For him, rights form part of the intellectual activity of a self-assertive autonomous individual. It is inevitable for moderate communitarianism to recognize "the intrinsic worth and dignity of the individual person" (Gyekye 1997, 40). The individual is both social and autonomous:

The capacity for self-assertion that the individual can exercise presupposes, and in fact derives from, the autonomous nature of the person. By autonomy, I do not mean self-completeness but the having of a will, a rational will of one's own, that enables one to determine at least some of one's own goals and to pursue them, and to control one's destiny (Gyekye 1997, 54). 
On the autonomy of the individual, Gyekye further contends:

In the light of the autonomous (or near autonomous) character of its activities, the communitarian self cannot be held as a cramped or shackled self, responding robotically to the ways and demands of the communal structure. The structure is never to be conceived as reducing a person to intellectual or rational inactivity, servility and docility (Gyekye 1997, 55-56).

However, Gyekye's attempt at ascribing equal worth to both individual rights and social responsibility is unsuccessful because he places more value on the community than on the individual. His moderate communitarianism subscribes to the traditional communitarian primacy thesis, which asserts the moral supremacy of the community over the individual (Gyekye 1997, 66). What is more, though Gyekye recognizes the rights of the individual, he never considers them to be the primary social value. Instead, the good of the community takes precedence over that of the individual. As a matter of fact, the recognition of individual rights under Gyekye's moderate communitarianism is for the sake of the community, not that of the individual. The individual's capacity for evaluating many of the practices of his/her community deserves recognition because it serves the overall community interest (Gyekye 1997, $57,62-63)$.

Thus although Gyekye argues for the partial constitution of the individual by social relationships, he, like unrestricted communitarians, accepts the communitarian primacy thesis - the moral supremacy of the community over the individual (Gyekye 1997, 71). This blurs his distinction between restricted (moderate) and unrestricted communitarianism. Thus unknown to Gyekye, most of his arguments in support of moderate communitarianism reinforce the unrestricted communitarianism which he rejects. In other words, Gyekye's communitarianism is not moderate because like unrestricted communitarianism, it is based on the parent-child model. Therefore while ordinarily moderate communitarianism emphasizes the need to balance individual rights and social responsibilities, Gyekye's communitarianism emphasizes the supremacy of the community over the individual.

What does Gyekye's recognition of rights amount to? The problem is partly conceptual. The word "recognition" is open to various interpretations. Does Gyekye's 
recognition of rights really make him a moderate communitarian? According to the Cambridge International Dictionary of English, "Recognition" partly means "acceptance". The word "accepted" can replace the word "recognized" in the sentence "Michael Jackson was a recognized authority in Pop Music". However, no communitarian accepts individual rights as the ultimate value.

Alternatively, "recognition" can mean "being able to identify something or somebody”. If I identify a Korean in a group of Kenyans, then a form of recognition has taken place. However, the identification of the said Korean among the Kenyans has insignificant moral weight if he/she is not treated in any special way. The recognition of the Korean reaches another level if, after he/she has been identified, he/she is specially honoured.

A more sophisticated meaning of the word "recognition" is part of Russell Hanson's interpretation of the word "seeing". According to Hanson, "seeing is experiential. A retinal reaction is only a physical state - a photochemical excitation" (Hanson 1972, 6). Someone may have visual contact with a particular object but still be unable to recognize it. For instance, if a non-physicist is ushered into a standard physics laboratory, he/she may have visual contact with certain pieces of equipment, but be unable to identify them as conical flask, bunsen burner, bell jar, test tube and microscope. Even if the non-physicist is presented with the list of names for all the equipment in the lab, he/she may still not be completely free from ignorance about the usefulness of each piece of equipment. Another level of recognition is achieved if the non-physicist is well informed about the utility of the equipment. The key point is that the visual contact with the external objects is not a sufficient condition for recognizing them. I may be able to identify a golden pen placed on the table: I may even know that it is used to write, without knowing that it is the most durable of all pens. Now, what is the point? As hinted above, Gyekye's recognition of rights offers a weak support for moderate communitarianism.

It is also noteworthy that the general moderate communitarian attempt to balance rights and responsibilities is not always practicable. This is due to the fact that there are instances when rights and responsibilities are in conflict. For example, the 
exercise of political rights does not always serve the common good. Thus the right to vote does not compel voters to pick the best candidate. As such, a voter's personal judgment may run contrary to the general community good. Similarly, the right to free choice of religion is normally considered to be more important than the good of the community, although the communal good might be enhanced if each individual was persuaded or compel to embrace a single, communal religion (Rachels 1996, 364). It is therefore clear that the reconciliatory approach with regard to individual rights and social responsibilities is not always successful. If this is granted, the debates between communitarians and their rivals such as liberals and libertarians regarding the primacy thesis continue.

Thus though Gyekye seems to have been attempting to narrow the gap between communitarianism and its traditional rivals (chiefly liberalism and libertarianism), his attempt is unsuccessful. His defense of moderate communitarianism ends up being a defense of the unrestricted communitarianism which he intends to reject. Gyekye's acceptance and defense of the primacy thesis makes him (though unknown to him) not only an unrestricted but also an unrepentant communitarian.

\section{Gyekye's Communitarian Primacy Thesis: Restricted or Unrestricted?}

Gyekye's estimation of individual rights in his version of moderate communitarianism is demonstrated in his support for the communitarian primacy thesis. Gyekye rejects what he claims to be the unrestricted communitarianism of Michael Sandel, Charles Taylor and Alasdair MacIntyre. According to Gyekye, these communitarians are of the view that "the politics of rights should be given up and replaced with the politics of the common good" (Gyekye 1997, 62). However, Gyekye's claim that these communitarians do not recognize rights is misleading. As a matter of fact, the western philosophers mentioned by Gyekye do recognize individual rights almost in the same way that he does.

Sandel's critique of liberalism does not amount to the rejection of rights, but only advocates the limit of rights (Sandel 1983). Sandel accepts, just like Gyekye, the 
communitarian primacy thesis. Furthermore, the unrestricted communitarianism of Charles Taylor, like the moderate communitarianism of Gyekye, recognizes the individual's capacity for autonomy. However, the extra point which Taylor makes, and which I think Gyekye would accept, is that such a capacity can only flourish in a human community (Taylor 1992, 33). Moreover, the individual's right to community membership is well developed in Michael Walzer's Spheres of Justice (1983). For him, membership of the community is the primary social good shared among members. Membership, for natural members, is a right. Those who are born into the community by parents who are also members have a right to membership. So, Walzer's communitarianism is compatible with rights. Thus contrary to Gyekye's position, the unrestricted communitarianism of Sandel, Taylor and Walzer recognizes rights.

Gyekye states that rights are not to be asserted or insisted on with "belligerency, for communal values such as generosity, compassion, reciprocities and mutual sympathies" are far more important than rights. Moderate communitarianism "cannot be expected to be obsessed with rights" (Gyekye 1997, 65). The communitarian society, perhaps like any other type of human society, deeply (uncompromisingly) cherishes the social value of peace, harmony, stability, solidarity and mutual reciprocities and sympathies. In the case of a moral clash between the rights of the individual and these communal values, the communal values ought to take precedence over the rights of the individual. Gyekye's primacy thesis is, like that of Sandel (1983, 1) and Taylor (1992), supported by the social nature of the individual. The individual's relational character defined by his/her natural sociality "immediately makes her naturally oriented to other persons with whom he or she must live" (Gyekye 1997, 67). This is in perfect agreement with Sandel's idea of limiting rights and Taylor's view that rights can only flourish in the community. Gyekye further contends that in the event of any anti-social activities by an individual, the community will have to take the steps necessary to maintain its integrity and stability (Gyekye 1997, 65). It is noteworthy that he never states the limit of the steps the community could justifiably take against recalcitrant members. 
According to Gyekye, The individual ought to develop a caring attitude with respect to the well-being of others. This entails the obligation to show concern for the welfare of others, and commitment to refrain from harming others. The responsibilities to fellow community members are not the product of any form of contract, but are rather derived from human social nature which, according to Gyekye, "implicates the individual in a web of moral obligations, commitments and responsibilities" for the sake of the common good (Gyekye 1997, 71).

There is therefore no difference between the unrestricted communitarianism rejected by Gyekye and the moderate communitarianism he defends. As earlier noted, Gyekye's recognition of rights (irrespective of the degree) is not for the sake of the individual but for the sake of the community. The individual is valued basically because he/she is valuable to the community. Thus Gyekye treats the individual, contrary to Immanuel Kant's admonition, not as an end but as a means. This is further evident when Gyekye writes:

At the practical level, communitarianism would realize that allowing free rein for the exercise of individual rights, which obviously includes the exercise of the unique qualities, talents and dispositions of the individual, will enhance the cultural development and success of the community ... Though rights belong primarily to the individuals, insofar as their exercise will often directly or indirectly, be valuable to the larger society, they ought to be recognized by the communitarian theory (Gyekye 1997, 64).

Gyekye's words above articulate an undiluted unrestricted communitarianism. The goal of Gyekye's moderate communitarianism is still the moral protection of the community. Both moderate and unrestricted communitarianism celebrate the community, not the individual.

From the foregoing observations, it is clear that the gap between the moderate communitarianism which Gyekye defends and the unrestricted communitarianism which he rejects is not as wide as he believes it to be. However, I am not arguing that moderate and unrestricted communitarianism are the same. Rather, the point is that the distinction between them, as presented by Gyekye, is not clear.

It is also important to briefly respond to Gyekye's view of the moral status of the individual. Though Gyekye maintains that the individual is only partially constituted 
by the community, the relationship between the individual and the community, as he presents it, is still based on the parent-child model. The community nurtures the individual just as the parent nurtures the child. Further, relationships among members of the community ought to be regulated by love and shared values just as is the case in a nuclear family (Gyekye 1997, 66). In other words, the natural bond among members of a community gives rise to the need to fulfill certain responsibilities towards the community.

However, Gyekye's attempt to base the relationship between the individual and the community on the parent-child model is unsuccessful. According to Immanuel Kant, the rightness or wrongness of an action is independent of its consequences. For Kant, duty is for the sake of duty (Kant 1989, 253-287). If it is the parents' duty to mind the child, the child's responsibilities towards the parents, later in life, could not be equally justifiably supported by the original duty (the minding of the child). The minding of the child is not optional but a duty incumbent on the parents. The duty ought to be performed even if it would yield no dividends in the future.

Similarly, the communitarian argument that the community nurtures (either partly or wholly) the individual and provides the structure that makes the flourishing of the individual possible offers a weak justification for the individual's responsibility towards the community later in life (Taylor 1992, 36). Nevertheless, I am not suggesting that the child ought not to mind his/her parents, or that the individual ought not to fulfill his/her obligations towards the community. My point is that the responsibilities in either case could not be plausibly justified by the initial responsibilities performed by either the parents (in the case of the child) or the community (in the case of the individual). The main reason the parents ought to mind the child is because the latter is vulnerable before he/she reaches a certain age. Any attempt to treat the parents' responsibilities towards the child as investments which ought to yield some economic or non-economic dividends later in life degrades the initial duty. Furthermore, the legitimate reason why the child (now an adult) ought to mind his/her aged parents is because they are equally vulnerable and weak, not because they minded him/her as a child. Ordinarily, those who support the needy do so not because those needy nurtured them as little children. 
Though Gyekye's moderate communitarianism aims at the recognition of rights, it stresses the primacy of love over justice, contending that love (not justice) is the first virtue of social institutions (Gyekye 1997, 72). The emphasis on love should be expected. Communitarianism in general emphasizes the social values of friendship among members of a community. However, Gyekye's insistence on the primacy of love undermines his moderate communitarianism. No rival theory to communitarianism (moderate or non-moderate) advocates any form of hatred. Neither liberalism nor libertarianism denies the social value of love. Each, at best, demands for the free choice of those to love. The liberal or libertarian demand for the free choice of who to love is a position communitarians need not reject. In practice, it is impossible for every member of the community to exhibit the same degree of love to every other member. Members of a typical communitarian community are not expected to keep the same friends, marry the same husbands or wives, eat from the same plate and share clothes. If this is granted, then it follows that even a communitarian community would allow members the freedom to choose who to love.

If the last point is accepted, in such a community the freedom to choose would be primary while love would be a secondary value. So Gyekye's attempt to recognize rights is not absolutely new. Thus the primacy of love is a liability for Gyekye's moderate communitarian proposal which aims at the recognition of the individual's capacity for choice. The claim that love rather than justice is the first virtue of social institutions jeopardizes the effort of treating the individual and the community with equal respect. Gyekye's insistence on the primacy of love therefore confirms his unrestricted communitarian orientation, as it agrees with the old or unrestricted communitarian primacy thesis which emphasizes the moral supremacy of the community.

As a matter of fact, love and justice are not mutually exclusive. They could simultaneously be the first virtues of social institutions. After all, it is quite possible for two pupils to come first in a school examination. Again, respecting someone's right to choose his/her friends could be one of the ways to demonstrate our love towards him/her. 


\section{Conclusion}

Is Professor Gyekye a moderate communitarian or simply a communitarian? This article has contended that his arguments in defense of moderate (restricted) communitarianism inadvertently support unrestricted communitarianism. This becomes evident on the basis of several considerations.

First, both moderate and unrestricted communitarianism are based on the parent-child model. The child is, either partly or wholly, nurtured by the parents, and has certain responsibilities towards the parents that nurtured him or her. Similarly, having being partly nurtured by the community, the individual ought to perform his or her duties towards the community. We have argued that this position is not moderate but unrestricted communitarianism.

Second, Gyekye, like unrestricted communitarians, stresses the primacy of love, which he considers to be the first virtue of social institutions. We have argued that this view jeopardizes the moderate communitarian attempt to balance individual rights and social responsibilities. A project that sets out to treat the individual and the community equally cannot justifiably prioritize either one of them. Besides, the fact that the primacy of love could be used by both the moderate and unrestricted communitarians undermines the strength of the arguments in support of moderate communitarianism. What is more, the priority of love over justice is superfluous since they are not mutually exclusive. The equal treatment of love and justice would have strengthened Gyekye's arguments for moderate communitarianism than the point he makes about the priority of love over justice.

Third, although Gyekye recognizes the individual's rights, this recognition is for the sake of the community rather than the individual. Thus both Gyekye's moderate communitarianism and unrestricted communitarianism grant individual rights the same degree of recognition. 
In the light of the foregoing discussion, we conclude that Gyekye is a communitarian, not a moderate communitarian as he claims to be. His acceptance of the communitarian primacy thesis is contrary to the moderate communitarian attempt to balance individual rights and social responsibilities. Besides, contrary to Gyekye's view, the article argues that unrestricted communitarianism recognizes individual rights.

\section{References}

Aristotle. 1989. "Nicomachean Ethics". Hutchins, Robert Maynard ed. Great Books of the Western World. Chicago: William Benton.

Cambridge International Dictionary of English. Cambridge: Cambridge University Press, 1996.

Dworkin, R. 1977. Taking Rights Seriously. London: Duckworth.

Etzioni, A. 1998. The Essential Communitarian Reader. New York: Rowman \& Littlefield.

Gyekye, K. 1997. Tradition and Modernity. New York: Oxford University Press.

--. 2003. African Cultural Values. Accra: Sankofa.

Hanson, R. 1972. Patterns of Discovery. London: Cambridge University Press.

Kant, I. 1989. "Fundamental Principles of the Metaphysics of Morals". Hutchins, Robert Maynard ed. Great Books of the Western World. Chicago: William Benton.

Rachels, J. 1996. “The Morality of Euthanasia”. Bonevac, Daniel ed. Today's Moral Issues: Classic and Contemporary Perspectives. London: Mayfield.

Rawls, J. 1995. A Theory of Justice. Cambridge: Harvard University Press.

Sandel, M. 1983. Liberalism and the Limits of Justice. Cambridge: Cambridge University Press.

Taylor, C. 1992. "Atomism". Shlomo, Avinery and De-Shalit Avner eds. Communitarianism and Individualism. New York: Oxford University Press.

Walzer, M. 1983. Spheres of Justice: A Defence of Pluralism and Equality. Oxford: Basil Blackwell. 